\title{
Workloads, strain processes and sickness absenteeism in nursing ${ }^{1}$
}

\author{
Vivian Aline Mininel2 \\ Vanda Elisa Andres Felli ${ }^{3}$ \\ Everaldo José da Silva ${ }^{4}$ \\ Zelinda Torri ${ }^{5}$ \\ Ana Paula Abreu \\ Maria Tereza Afonso Branco ${ }^{6}$
}

\begin{abstract}
Objective: to analyze the workloads, strain processes and sickness absenteeism among nursing workers from a teaching hospital in the Brazilian Central-West. Method: a descriptive and crosssectional study was developed with a quantitative approach, based on the theoretical framework of the social determination of the health-disease process. Data were collected between January and December 2009, based on records of complaints related to occupational exposure among nursing professionals, filed in the software Monitoring System of Nursing Workers' Health. For the sake of statistical analysis, relative and absolute frequencies of the variables and the risk coefficient were considered. Results: 144 notifications of occupational exposure were registered across the analysis period, which represented $25 \%$ of the total nursing population at the hospital. The physiological and psychic workloads were the most representative, corresponding to $37 \%$ and 36\%, respectively. These notifications culminated in 1567 days of absenteeism for disease treatment. Conclusions: the findings evidence the impact of occupational illnesses on the absenteeism of nursing workers, and can be used to demonstrate the importance of institutional investments in occupational health surveillance.
\end{abstract}

Descriptors: Nursing; Occupational Health; Occupational Risks; Absenteeism.

\footnotetext{
${ }^{1}$ Supported by Fundação de Amparo à Pesquisa do Estado de São Paulo (FAPESP), process \# 2007/59740-2.

${ }^{2} \mathrm{PhD}, \mathrm{RN}$.

${ }^{3} \mathrm{PhD}$, Associate Professor, Escola de Enfermagem, Universidade de São Paulo, São Paulo, SP, Brazil.

${ }^{4}$ MSc, Coordinator, Coordenação de Atenção à Saúde, Universidade de Brasília, Brasília, DF, Brazil.

${ }^{5}$ Specialist in Public Health, RN, Coordenação de Atenção à Saúde, Universidade de Brasília, Brasília, DF, Brasil.

${ }^{6}$ Specialist in Management Hospital, RN, Hospital Universitário de Brasília, Brasília, DF, Brazil.
}

Corresponding Author:

Vanda Elisa Andres Felli

Universidade de São Paulo. Escola de Enfermagem

Av. Dr. Enéas de Carvalho Aguiar, 419

Bairro: Cerqueira César

CEP: 05403-000, São Paulo, SP, Brasil.

E-mail: vandaeli@usp.br
Copyright (c) 2013 Revista Latino-Americana de Enfermagem This is an Open Access article distributed under the terms of the Creative Commons Attribution Non-Commercial License (CC BY-NC).

This license lets others distribute, remix, tweak, and build upon your work non-commercially, and although their new works must also acknowledge you and be non-commercial, they don't have to license their derivative works on the same terms. 


\section{Introduction}

The human body's different reactions to work, manifested through pleasure and satisfaction, but also through pain, disease, strain, psychic and physical suffering, which trigger disabilities, absenteeism, early retirement and even death among nursing workers, have been focused on in different Brazilian studies ${ }^{(1-5)}$.

Based on the theoretical reference framework of the social determination of the health disease process $^{(6-7)}$, the relation between factors of exposure (workloads) and the consequent potential or manifested processes of physical and/or psychic strain, a disease profile characteristic of these workers can be drawn ${ }^{(7)}$.

The workloads that nursing workers are exposed to during their workday are classified as biological, physical, chemical, mechanic, physiological and psychic ${ }^{(8)}$, even if they are unaware of the risks inherent in this exposure.

Brazilian studies characterize the workloads and the effects of this exposure, such as absenteeism, strain processes, occupational illnesses and accidents caused in the nursing team, in different environments, conditions, organizations and professional contexts ${ }^{(9-12)}$.

Despite the doubtless relevance of the theme, not all employers are willing to invest in resources to interrupt or minimize the occupational exposure and illness process, nor in actions to promote quality of life at work

Therefore, the impacts of this reality need to be evidenced, not only on workers' health, but also for the employers, including financial losses and a drop in service quality resulting from absences, medical leaves, leaves of absence and presenteeism, in the attempt to trigger a change of attitude to enhance occupational health surveillance.

In that sense, the Monitoring System of Nursing Workers' Health (SIMOSTE)(13), a software developed and patented by the Research Group "Health Studies of Nursing Workers" at the University of Sao Paulo School of Nursing, was implemented at seven hospitals in different Brazilian regions to register nursing workers' occupational exposure and its consequences, permitting the monitoring of these conditions through indicators.

Thus, the aim in this study is to describe the workloads, the respective strain and the sickness absenteeism among nursing workers in one of the setting of the SIMOSTE Project, located in the Brazilian Central-West.

\section{Method}

A descriptive and cross-sectional study with a quantitative approach was conceived within the theoretical framework of the social determination of the health and disease process ${ }^{(6-7)}$. The quantitative approach, as a dimension of quality, sustained by the dialectical law of the "transition from quantity to quality"(14), permits establishing the relation between work as a social category and occupational health.

The study was developed at a teaching hospital in the Brazilian Central-West, hereinafter called HUCO. At this institution, health care services are delivered and teaching and research activities take place. At the time of data collection, the institution offered 240 hospital beds, with a staff of approximately 2,230 workers, including statutory workers, teachers and administrative staff affiliated with the university, Ministry of Health official and outsourced employees.

The nursing professionals, who served as the study population, corresponded to 572 workers $(25.67 \%$ of total staff), with 120 (20.9\%) baccalaureate nurses, four $(0.7 \%)$ nursing technicians and $448(78.4 \%)$ auxiliary nurses. The small percentage of nursing technicians is due to the non recognition of this professional category in the hospital staff at the time of study - a reality that has been changing.

The cases consisted of nursing workers who turned to the Specialized Safety Engineering and Occupational Health Service (SESMT) with occupational health complaints (accidents, illnesses or symptoms) between November 2008 and October 2009. After an analysis of this population's files, the data were included in SIMOSTE by a previously trained nurse who worked at the study hospital, using the computer on which the software had been installed.

The data registered on the local computer were periodically forwarded to the server that hosts SIMOSTE through an online interface, where they were validated by an expert committee and stored to elaborate the indicators and analyses. Any doubts as to data consistency were checked with the field nurse.

SIMOSTE was constructed within the framework of the social determination of the health-disease process and is based on the categories work process, workloads, strain process and outcomes, which are the three modules that structure the system. The previously trained professional identifies the workloads based on 
the worker's complaint and the outcome produced, and the strain processes registered in SIMOSTE are grouped in accordance with the International Classification of Diseases version 10 (ICD10).

The stored data were extracted from SIMOSTE and inserted in an Excel worksheet. For the analysis, relative and absolute frequencies and the Risk Coefficient (RC) were used, which is calculated by dividing the number of events that occurred at the same place and time by the total number of people exposed to the events ${ }^{(15)}$.

This project received approval from the Research Ethics Committee at the University of São Paulo School of Nursing, process 718/2008/CEP-EEUSP.

\section{Results}

In 2009, 144 workload-related notifications were registered, 129 (89.58\%) of which involved female and $15(10.42 \%)$ male workers. These notifications were distributed as described in Table 1.

Table 1 - Number of notifications according to professional category. Central-West, Brazil, 2009

\begin{tabular}{lccc}
\hline \multicolumn{1}{c}{ Professional category } & N & $\%$ & RC \\
\hline Baccalaureate nurses $(n=120)$ & 14 & 9.7 & 11.7 \\
Nursing technicians $(n=4)$ & 2 & 1.4 & 50 \\
Auxiliary Nurses $(n=448)$ & 128 & 88.9 & 28.6 \\
Total $(n=572)$ & 144 & 100 & 25.2 \\
\hline
\end{tabular}

Source: SIMOSTE, 2009

As regards the professional category, the auxiliary nurses are the most frequent victims, with $89 \%$ of the notifications. On the other hand, the nursing technicians show the highest risk coefficient, followed by the auxiliary nurses.

The age range between 31 and 40 years is the most representative among the professionals, with $37.5 \%$ of the notifications, followed by the range between 41 and 50 years with $36.8 \%$. The groups between 21 and 30 years and between 51 and 60 years correspond to $10.4 \%$ and $11.1 \%$, respectively, and the least representative range relates to professionals over 60 years of age $(4.2 \%)$.

Approximately $56 \%$ of the workers with notification in SIMOSTE indicated a monthly income between $\mathrm{R} \$$ $1,501.00$ and $R \$ 2,000.00,25 \%$ between $R \$ 500.00$ and $R \$ 1,500.00$ and $17 \%$ over $R \$ 2,001.00$.

The results demonstrate that $99.3 \%$ (143) of the notifications involved workers with a weekly work journey between $10 \mathrm{~h}$ and $36 \mathrm{~h}$ and that $82 \%$ were statutory public servants.

In general, all hospital services were represented in the notifications made during the study period. The outpatient clinic was responsible for $38.9 \%$ of the notifications, followed by the surgery room (obstetric center, surgical center and sterilization center) with $26.4 \%$ and the gynecology and obstetrics services with $10.4 \%$. The intensive care unit corresponded to $6.9 \%$ of the notifications, the medical clinic to $6.2 \%$, pediatrics and maternity to $5.6 \%$ and the other services $5.6 \%$.

The results related to the notified workloads have been described in Table 2.

Table 2 - Distribution of notifications according to workloads. Central-West, Brazil, 2009

\begin{tabular}{|c|c|c|}
\hline Workloads & $\mathbf{N}$ & $\%$ \\
\hline Physiological & 60 & 37.5 \\
\hline Psychic & 58 & 36.2 \\
\hline Biological & 23 & 14.4 \\
\hline Mechanic & 12 & 7.5 \\
\hline Physical & 4 & 2.5 \\
\hline Chemical & 3 & 1.9 \\
\hline Total & 160 & 100 \\
\hline
\end{tabular}

Source: SIMOSTE, 2009

The number of referred workloads (160) is higher than the number of notifications made (144), showing interaction between two or more workloads, like psychic workloads with other types.

Table 3 reveals the exhaustion processes that result from exposure to the workloads, notified in SIMOSTE through the International Classification of Diseases version 10 (ICD10) and the correlation with the days of absence during the same period.

Diseases of the musculoskeletal system and connective tissue represent the main health problem, corresponding to about $21 \%$ of the notifications, followed by mental and behavioral disorders (15.3\%) and respiratory problems (13.9\%). On the other hand, the analysis of the number of days of leave indicates that the diseases of the circulatory system, which add up to seven notifications, causes 353 days of leave; while the 30 notifications due to diseases of the musculoskeletal system and connective tissue lead to 325 days of leave; and the 22 notifications resulting from mental and behavioral disorders resulted in 246 days of leave. 
Table 3 - Distribution of notified processes of exhaustion according to ICD10 groups and days of absence counted. Central-West, Brazil, 2009

\begin{tabular}{|c|c|c|c|}
\hline Disease groups - ICD10 & $\mathbf{N}$ & $\%$ & Days of absence \\
\hline Diseases of the musculoskeletal system and connective tissue & 30 & 20.7 & 325 \\
\hline Mental and behavioral disorders & 22 & 15.3 & 246 \\
\hline Diseases of the respiratory system & 20 & 13.9 & 98 \\
\hline Convalescence & 20 & 13.9 & 294 \\
\hline External causes of morbidity and mortality & 16 & 11.1 & 23 \\
\hline Diseases of the circulatory system & 7 & 4.9 & 353 \\
\hline Diseases of pregnancy, childbirth and the puerperium & 7 & 4.9 & 81 \\
\hline Diseases of the digestive system & 4 & 2.8 & 40 \\
\hline Diseases of the genitourinary system & 3 & 2.1 & 11 \\
\hline Diseases of the eye and adnexa & 3 & 2.1 & 19 \\
\hline Diseases of the skin and subcutaneous tissue & 2 & 1.4 & 6 \\
\hline Diseases of the ear and mastoid process & 1 & 0.7 & 7 \\
\hline Diseases of the nervous system & 1 & 0.7 & 2 \\
\hline No information* & 8 & 5.5 & 62 \\
\hline Total & 144 & 100 & 1567 \\
\hline
\end{tabular}

* leaves without correlated ICD10

Source: SIMOSTE, 2009

Convalescence, which figures in the ICD10 group related to the health recovery periods after surgery or treatment, also stood out in terms of the days of absence it caused (294).

Table 4 shows the recurrence of notifications among the nursing workers during the study period.

Table 4 - Recurrent notifications across analysis period. Central-West, Brazil, 2009

\begin{tabular}{lcc}
\hline \multicolumn{1}{c}{ Number of notifications } & Quantity & $\%$ \\
\hline 01 notification & 92 & 62.89 \\
01 recurrent notification & 29 & 20.14 \\
02 recurrent notifications & 13 & 9.03 \\
03 recurrent notifications & 3 & 2.08 \\
04 or more recurrent notifications & 7 & 4.86 \\
Total & 144 & 100 \\
\hline
\end{tabular}

Source: SIMOSTE, 2009
The recurrence of the same worker's notifications should be analyzed in detail, as it can indicate inappropriate or unfavorable conditions for work or some occupational health condition that is not receiving proper treatment, with a possible relapse. Therefore, Table 5 details the profile of workers with four or more recurrent notifications during the study period and the disease-related absenteeism.

The data demonstrate that, frequently, the recurrence of a notification derives from a problem the worker has already referred and which may not have been solved. Leaves did not exceed 15 days in any case; the leaves are short, frequent and palliative.

Table 5 - Workers with four or more recurrent notifications, according to causes of recurrence (ICD10 groups), age range, work sector and days of absence. Central-West, Brazil, 2009

\begin{tabular}{|c|c|c|c|c|c|}
\hline Professional category & Age range & Work sector & Causes of recurrence (ICD10) & $\mathbf{N}$ & $\begin{array}{l}\text { Days of } \\
\text { absence }\end{array}$ \\
\hline \multirow[t]{3}{*}{ Auxiliary Nurse } & \multirow[t]{3}{*}{$31-40$ years } & \multirow{3}{*}{$\begin{array}{l}\text { Gynecology and } \\
\text { Obstetrics }\end{array}$} & Mental and behavioral disorders & 2 & \multirow[t]{3}{*}{25} \\
\hline & & & Diseases of the musculoskeletal system and connective tissue & 1 & \\
\hline & & & Convalescence & 1 & \\
\hline \multirow[t]{3}{*}{ Auxiliary Nurse } & \multirow[t]{3}{*}{$41-50$ years } & \multirow[t]{3}{*}{ Outpatient clinic } & Mental and behavioral disorders & 2 & \multirow[t]{3}{*}{40} \\
\hline & & & Diseases of the musculoskeletal system and connective tissue & 1 & \\
\hline & & & Diseases of the respiratory system & 1 & \\
\hline
\end{tabular}


Table 5 - (continuation)

\begin{tabular}{|c|c|c|c|c|c|}
\hline Professional category & Age range & Work sector & Causes of recurrence (ICD10) & $\mathbf{N}$ & $\begin{array}{l}\text { Days of } \\
\text { absence }\end{array}$ \\
\hline \multirow[t]{2}{*}{ Auxiliary Nurse } & $41-50$ years & Outpatient clinic & Mental and behavioral disorders & 3 & 32 \\
\hline & & & Diseases of pregnancy, childbirth and the puerperium & 2 & \\
\hline Auxiliary Nurse & $41-50$ years & Outpatient clinic & Diseases of the musculoskeletal system and connective tissue & 4 & 41 \\
\hline \multirow[t]{2}{*}{ Auxiliary Nurse } & $41-50$ years & Outpatient clinic & Diseases of the musculoskeletal system and connective tissue & 1 & 40 \\
\hline & & & Convalescence & 3 & \\
\hline \multirow[t]{3}{*}{ Auxiliary Nurse } & $41-50$ years & Outpatient clinic & Mental and behavioral disorders & 1 & 33 \\
\hline & & & Diseases of the musculoskeletal system and connective tissue & 2 & \\
\hline & & & Diseases of the respiratory system & 1 & \\
\hline \multirow[t]{2}{*}{ Baccalaureate nurse } & $31-40$ years & Surgery unit & Mental and behavioral disorders & 2 & 28 \\
\hline & & & Diseases of the musculoskeletal system and connective tissue & 1 & \\
\hline
\end{tabular}

Source: SIMOSTE, 2009

\section{Discussion}

The results reveal a large number of occupational health related notifications during the study period, with a mean 12 notifications per month. The risk coefficient (RC) for nursing at the institution corresponded to 25.2 during the period and was higher for nursing technicians and auxiliaries. This may be due to the characteristics of these professional categories' activities, responsible for most direct care to patients ${ }^{(10,16)}$.

In a study about accidents that involved piercingcutting materials at a public hospital in the interior of Sao Paulo State, the $\mathrm{RC}=15.13$ for accidents that involved this equipment among auxiliary nurses(8). In another study, undertaken at six public hospitals in the Federal District, found an $R C=39.1$ for accidents involving biological material among health professionals ${ }^{(17)}$. A result very similar to the present found an $\mathrm{RC}=26.47$ for occupational accidents among auxiliary nurses at a teaching hospital in the Federal District(18).

The present study data are in accordance with earlier studies when considering the high occupational risk exposure level nursing workers are exposed to in the hospital context.

Concerning the age ranges of the workers that filed notifications in SIMOSTE, in a study of nursing workers at a teaching hospital in the Federal District, similar results were found. The highest frequency of occupational accidents was found among professionals between 31 and 50 years of age. The authors attributed these results to the associated population's long experience, associated with non-compliance with the rigor needed to prevent occupational accidents, deriving from the non-surveillance of their application $^{(17)}$.
Studies involving hospital nursing professionals demonstrated that most of these professionals work double or triple shifts, reflecting in few hours for leisure, rest, physical exercise, quality of sleep, besides increased exposure to the workloads and risks present in their work environments ${ }^{(12,19-20)}$. That was not observed in the present study, possibly because the population has a sole job contract (up to 36 hours per week), something rare among Brazilian nursing professionals.

The physiological workloads prevailed in the notifications in SIMOSTE. In a study to investigate exposure to these workloads among outpatient nursing workers indicated exposure to excessive weight handling during their activities, as well as the predominance of standing, uncomfortable or inappropriate positions during the work day ${ }^{(11)}$.

The psychic workloads were also relevant in the study context. As a result of the precarious work organization, in combination with the institutionally established vertical relations, nursing becomes increasingly exposed to these workloads, through moral harassment, organizational pressure, restricted supervision, lack of autonomy, power abuse and lack of collective defense. Some forms of strain deriving from this type of exposure were also indicated in a specific study about psychic workloads, including sleep and insomnia, gastritis, increased blood pressure, anxiety, insecurity, depression and stress ${ }^{(12)}$.

The biological workloads, which rank third in the notifications, generally derive from accidents that involve piercing and cutting material and from contact with body fluids and secretions ${ }^{(16-18)}$. The physical and chemical workloads corresponded to the smallest notification percentages during the analysis period. 
It is interesting to note that the hospital environment offers a range of situations that expose the workers to the different workloads - a process that can take form abruptly (as workplace accidents or accident to and from work) or in a gradual exponential form, through strain and illnesses. Similar studies involving nursing workers in Brazil converge towards the same conclusion $^{(7-8,21)}$.

Diseases of the musculoskeletal system and connective tissue and mental disorders were the most representative in the referred groups of diseases. Work-related Musculoskeletal Disorders (WMSD) show the highest incidence levels among nursing workers and are the main causes of leaves in this category(22). This is due to the nursing professionals' tasks, which demand constant and intense physical efforts, mostly in inappropriate positions and conditions.

Mental and behavioral disorders, equally relevant, end up triggering strain processes that cannot always be easily related to work and often are attributed to the individual's general lifestyle. In this study, depressive episodes were the most representative in this disease group, in accordance with the literature ${ }^{(23)}$.

The group of diseases of the respiratory system is associated with cases of sinusitis, tonsillitis and pharyngitis; only three cases were directly related with the flue H1n1, which affected the world population and caused different leaves in that period, also for suspected and unconfirmed cases of the disease.

Convalescence is related with health recovery associated to some kind of treatment, procedures or specific care. As the convalescence diagnosis was attributed without the sub-classification of the ICD10, the actual cause of the notification and its relation with work remained unknown.

One unexpected finding refers to the group of diseases related to the pregnancy period, which were included in SIMOSTE as work-related. In the present study, the relation between these conditions and the work environment could not be identified. This fact should be looked at in further depth, especially considering that nursing is a predominantly female profession, involving women of fertile age, making pregnancy a constant event in this public.

Another relevant research result is the number of recurrent notifications among the nursing workers. Among the 144 notifications, 52 related to workers who had filed a notification. This arouses reflections on the health profile of nursing, which increasingly indicates the chronic nature of work-related conditions and illnesses.

The notifications in SIMOSTE triggered 1567 days of absence from work due to diseases related to occupational exposure during the 12-month period. These lost workdays, if considered for a single worker, in consecutive days, would be equivalent to approximately four years and three months. It should be emphasized, however, that the absenteeism mentioned relates to different workers, at distinct or simultaneous times, and that not all cases related to periods of more than 15 days, which characterizes the severity of the health problems.

In line with the research findings, other studies demonstrate that the rates of diseaserelated absenteeism in nursing are very high, mainly due to the presence of risk factors in the work environment ${ }^{(24-25)}$

For the institution, this information is extremely important, as it permits recognizing individuals with recurrent complaints and absences, enhancing the individual assessment of cases and the proposal of the collective interventions needed.

Also, additional studies on the costs of the workdays lost are needed to demonstrate the financial losses the institution is incurring due to absenteeism, indicating the advantages of investing in actions aimed at health surveillance and the promotion of quality of life at work.

\section{Conclusion}

This study provided knowledge on the workloads, processes of illness or strain and sickness absenteeism among nursing workers from different hospital services, in a systematic manner, through SIMOSTE.

The physiological workloads prevailed, followed by the psychic workloads. The causes of absence from work were related to the illnesses grouped according to the ICD10, particularly diseases of the musculoskeleta system and connective tissue and mental and behavioral disorders.

It could be identified that the nursing workers are absent for less than 15 days, recurrently, frequently due to the same reasons, and that these short-term absences, when analyzed over a one-year period, represent a relevant number of workdays lost.

This study contributes to the advancement of nursing knowledge through the use of a technological tool for the collection and systematic analysis of data 
related to occupational exposure, permitting the actors' visualization of this context, as a possible instrument to propose reality-based interventions.

One study limitation was the impossibility to link occupational exposure with the workloads and the produced outcome (disease and absence).

Key to the health surveillance of nursing workers is to anticipate the identification of the risks inherent in this activity in order to intervene in the work reality early, granting safe conditions for its development - an objective that is permanently aimed for through the use of SIMOSTE in this and other project settings.

\section{Acknowledgments}

To members of the Research Group "Estudos sobre a Saúde do Trabalhador de Enfermagem" from Escola de Enfermagem da Universidade de São Paulo.

\section{References}

1. Shimizu HE, Couto DT, Haman EM. Pleasure and suffering in intensive care unit nursing staff. Rev. LatinoAm. Enfermagem. 2011;19(3):565-72.

2. Martins JT, Robazzi MLCC, Bobroff MCC. Prazer e sofrimento no trabalho da equipe de enfermagem: reflexão à luz da psicodinâmica Dejouriana. Rev Esc Enferm USP. 2010;44(4):1107-11.

3. Prestes FC, Beck CLC, Silva RM, Tavares JP, Camponogara S, Burg G. Prazer-sofrimento dos trabalhadores de enfermagem de um serviço de hemodiálise. Rev Gaucha Enferm. 2010; 31(4):738-45.

4. Abreu RMD, Simões ALA. Ausência por adoecimento na equipe de enfermagem de um hospital de ensino. Cienc Cuid Saude. 2009;8(4):637-44.

5. Carvalho LSF, Matos RCS, Souza NVDO, Ferreira REDS. Motivos de afastamento por licença de saúde dos trabalhadores de enfermagem. Cienc Cuid Saúde. 2010;9(1):60-6.

6. Laurell AC. A saúde-doença como processo social. In: Nunes ED, organizador. Medicina social: aspectos históricos e teóricos. São Paulo: Ed. Global; 1983. p. 133-58.

7. Laurell AC, Noriega M. Processo de produção em saúde: saúde e desgaste operário. São Paulo: Hucitec; 1989.

8. Silva VEAF, Kurcgant $P$, Queiroz VM. O desgaste do trabalhador de enfermagem: relação trabalho de enfermagem e saúde do trabalhador. Rev Bras Enferm. $1998 ; 51(4): 603-14$.
9. Costa TF, Felli VEA. Nursing workers' exposure to chemical products at a public universitary hospital in SãoPaulo city. Rev. Latino-Am. Enfermagem. 2005;13(4):501-8.

10. Balsamo AC, Felli VEA. Study of work accidents related to human body fluids exposure among health workers at a university hospital. Rev. Latino-Am. Enfermagem. 2006;14(3):346-53.

11. Sapia T, Felli VEA, Ciampone MHT. Problemas de saúde de trabalhadores de enfermagem em ambulatório pela exposição às cargas fisiológicas. Acta Paul Enferm. 2009:22(6):808-12.

12. Mininel VA, Baptista PCP, Felli VEA. Psychic workloads and strain processes in nursing workers of Brazilian university hospitals. Rev. Latino-Am. Enfermagem. 2011;19(2):340-7.

13. Baptista PCP, Felli VEA, Mininel VA, Karino ME, Silva SM, Tito RS, et al. A inovação tecnológica como ferramenta para monitoramento da saúde dos trabalhadores de enfermagem. Rev Esc Enferm USP. 2011;45(n.spe):1621-6.

14. Konder L. O que é dialética. 25 ed. São Paulo: Editora Brasiliense, 1982. p. 57-62.

15. Laurenti R, Mello Jorge MHP, Lebrão ML, Gotlieb SLD. Estatísticas de saúde. 2 ed. São Paulo: EPU; 2005.

16. Ribeiro EJG, Shimizu HE. Acidentes de trabalho com trabalhadores de enfermagem. Rev Bras Enferm. 2007;60(5):535-40.

17. Caixeta RB, Barbosa-Branco A. Acidente de trabalho com material biológico em profissionais de saúde de hospitais públicos do Distrito Federal. Cad Saúde Pública. 2005;21(3):737-46.

18. Pinho DLM, Rodrigues CM, Gomes GP. Perfil dos acidentes de trabalho no Hospital Universitário de Brasília. Rev Bras Enferm. 2007;60(3):291-4.

19. Mauro MYC, Veiga AR. Problemas de saúde e riscos ocupacionais: percepções dos trabalhadores de enfermagem em unidade materna infantil. Rev Enferm UERJ. 2008;16(1):64-9.

20. Spillen APM, Dyniewicz AM, Slomp MGFS. Qualidade de vida de profissionais de saúde em hospital universitário. Cogitare Enferm. 2008;13(1):88-95.

21. Mininel VA, Felli VEA. Management initiatives aimed at nursing quality or worklife. Ergonomia: Int J Ergon Human Factors. 2007;29:273-6.

22. Lelis CM, Battaus MRB, Freitas FCT, Rocha FLR, Marziale MHP, Robazzi MLCC. Distúrbios osteomusculares relacionados ao trabalho em profissionais de enfermagem: revisão integrativa da literatura. Acta Paul Enferm. 2012;25(3):477-82. 
23. Manetti ML, Marziale MHP. Fatores associados à depressão relacionada ao trabalho de enfermagem. Estud Psicol. 2007;12(1):79-85.

24. Silva DMPP, Marziale MHP. Condições de trabalho versus absenteísmo-doença no trabalho de enfermagem. Cienc Cuid Saúde. 2006;5(supl):166-72.

25. Sancinetti TR, Gaidzinski RR, Felli VEA, Fugulin FMT, Baptista PCP, Ciampone MHT, et al. Absenteísmodoença na equipe de enfermagem: relação com a taxa de ocupação. Rev Esc Enferm USP. 2009;43(esp 2):1277-83. 